\title{
Long Term Exposure to Manganese in Rural Well Water Has No Neurological Effects
}

\author{
P. Vieregge, B. Heinzow, G. Korf, H.-M. Teichert, P. Schleifenbaum and \\ H. - . Mösinger
}

\begin{abstract}
Background: There is debate on the neurological impact of chronic exposure to Manganese (MN). Methods: MN burden from rural well water was studied cross-sectionally in two proband cohorts from rural dwellings located in northern Germany. Both cohorts had exposure times for up to 40 years and were separated on the basis of well water MN content. Group A (41 subjects; mean age 57.5 years) was exposed to $\mathrm{MN}$ water contents of at least $0.300 \mathrm{mg} / \mathrm{l}$ (range 0.300 to 2.160 ), while group B (74 subjects; mean age 56.9 years) was exposed to concentrations of less than 0.050 $\mathrm{mg} / \mathrm{l}$. Both proband groups were homogenous with regard to age, sex, nutritional habits, and drug intake. Neurological assessments by clinical investigators blinded for proband's exposure status was done using structured questionnaires, standardized neurological examination with assessment of possible Parkinsonian signs by the Columbia University Rating Scale, and instrumental tests of fine motor coordination. Results: No significant difference in any neurological measure was found between groups. Results were not confounded by demographic and dietary features. Conclusion: Exposure to high body burden of $\mathrm{MN}$ does not result in detectable neurological impairment. Exposure to $\mathrm{MN}$ in drinking water does not seem to be a risk factor for idiopathic Parkinson's disease.
\end{abstract}

\begin{abstract}
RÉSUMÉ: L'exposition à long terme au manganèse dans l'eau de puits n'a pas de répercussion neurologique. Introduction: Les répercussions neurologiques d'une exposition chronique au manganèse (MN) demeurent une source de controverse. Méthodes: Nous avons effectué une étude transversale de la charge en MN chez deux cohortes de sujets habitant la campagne dans le nord de l'Allemagne. Chez les individus des deux cohortes, le temps d'exposition pouvait atteindre 40 ans. Le groupe A (4l sujets; 57.5 ans d'âge moyen) avait été exposé à de l'eau dont la teneur en MN était d'au moins $0.300 \mathrm{mg} /$ l (intervalle de 0.300 à 2.160), alors que le groupe B (74 sujets; 56.9 ans d'âge moyen) avait été exposé à des concentrations de moins de $0.050 \mathrm{mg} / \mathrm{l}$. Les deux groupes de sujets étaient homogènes quant à l'âge, au sexe, aux habitudes alimentaires et à la prise de médicaments. Des investigateurs cliniques ignorant le niveau d'exposition des sujets ont effectué une évaluation neurologique au moyen d'un questionnaire structuré, d'un examen neurologique standardisé avec évaluation des signes parkinsoniens au moyen de l'échelle de l'université Columbia lorsque pertinent, ainsi que des épreuves de motricité fine. Résultats: Nous n'avons pas observé de différence significative pour quelque mesure que ce soit entre les deux groupes. Les résultat n'étaient pas influencés par des particularités démographiques ou alimentaires. Conclusions: L'exposition à une charge corporelle élevée en MN ne provoque pas de déficit neurologique décelable. L'exposition au MN dans l'eau potable ne semble pas être un facteur de risque de la maladie de Parkinson.
\end{abstract}

Can. J. Neurol. Sci. 1995; 22: 286-289

Agents from drinking water sources have repeatedly been discussed as potentially relevant for the aetiology of neurodegenerative conditions such as amyotrophic lateral sclerosis and Alzheimer's disease. ${ }^{1,2}$ In idiopathic Parkinson's disease (PD), premorbid rural residence near wells for drinking water supply has raised speculations on the putative etiological role of water contents, ${ }^{3.4}$ such as metals or pesticides. ${ }^{5-8}$

Among the most frequently discussed elements in this respect is manganese (MN). $\mathrm{MN}$ is involved in basal ganglia metabolism inside and outside the dopaminergic system ${ }^{9-11}$ and is well known to cause secondary Parkinsonism accompanied by dystonia, mental disturbances and, eventually, by pyramidal tract signs. ${ }^{12,13}$ However, there is at present no evidence for an immediate role of this element in the pathogenesis of PD, as for

From the Department of Neurology (P.V., G.K.) and Institute of Medical Statistics and Documentation (H.-M.T.), Medical University of Lübeck, Lübeck; Institute of Environmental Toxicology (B.H.), Kiel; Public Health Authority of Kreis HerzogtumLauenburg (P.S., H.-U.M.), Ratzeburg, Federal Republic of Germany. RECEIVED FEBRUARY 8, 1995. ACCEPTED IN FINAL FORM APRIL 19, 1995.

Reprint requests to: Privatdozent Dr. med. Peter Vieregge, Department of Neurology, Medical University of Lübeck, Ratzeburger Allee 160, D-23538 Lübeck 
example, the post-mortem concentrations of $M N$ in various brain regions of PD patients and of healthy age-matched controls did not differ. ${ }^{14-16}$

Occupational studies in workers with long term exposure to $\mathrm{MN}$ have raised the suspicion of slight neurological effects from chronic exposure. ${ }^{17-18}$ Such workers had a higher rate of subjective complaints and of psychomotor impairment when tested instrumentally. The application of such instrumental tests seemed to be superior to conventional neurological examination in the detection of subtle neurological impairment. ${ }^{18}$ Therefore, we used similar methods to investigate whether longterm exposure to well water with high MN concentration may carry an analogous risk for neurological impairment; we also explored whether such exposure may provide a link for the epidemiological association between PD and rural well water supply. We also studied whether $\mathrm{MN}$ intake could be a cofactor that might have some kind of trigger function in the nigrostriatal compromise in PD. ${ }^{19}$

\section{Methods}

For decades many dwellings in rural Schleswig-Holstein, the most northern province of Germany, have had their own wells for supplying drinking water. By public health legislation, this well water is monitored for chemicals and bacteria. In 1991, a surveillance survey took place in a small southern rural area of the county Herzogtum Lauenburg with mainly agriculture and forestry but no steel or mining industries. The survey was combined with the cross-sectional investigation of a randomly selected group of right-handed residents above 40 years of age who had used their wells as the principal drinking water source for at least 10 years (range $10-40 \mathrm{yrs}$ ). To be eligible, their wells had to have a complete documentation of monitoring results for well water $\mathrm{MN}$ concentration for the last six years prior to this investigation. Participants were divided in two groups; those who continually consumed well water with a $\mathrm{MN}$ concentration of at least $0.300 \mathrm{mg} / \mathrm{l}$ (group A). A control group (B) was chosen from the same area, with the same preconditions and time frame. The water concentration for $\mathrm{MN}$ in the wells of these participants had never exceeded $0.050 \mathrm{mg} / \mathrm{l}$. The individuals of group A were matched to individuals of group B with respect to age, sex, nutritional habits, and drug intake. Subjects were excluded, if they had any history of occupation in the steel industry, if they adhered to any dietary restrictions or had ever taken CNS-relevant drugs, if they had diabetes mellitus, a history of stroke or treatment for any psychiatric condition, if there was any neuroorthopedic or related impairment of hand-finger function, or if they had poor vision.

Subjects were interviewed with a detailed, structured questionnaire for medical and occupational history, for habits and amounts of tobacco smoking and daily consumption of alcoholic and non-alcoholic beverages, for dietary habits (esp. fruits, vegetables, fish, milk products), and drug use. A modified German version of a standardized symptom list regarding accepted neurotoxicological complaints of $\mathrm{MN}$, pesticides, and solvents (analogous the Q-16-questionnaire: 20) was applied (maximum item score for highest degree of complaints: 20). Each participant underwent a complete, standardized neurological examination by the same certified neurologist with special experience in movement disorders who was blinded to the group status of the participants. Signs of parkinsonism were evaluated by the Columbia University Rating Scale (CURS: 21). Fine motor abilities of both hands were tested in randomized sequence between participants using a conventional apparatus ("motorische Leistungsserie": MLS: 22). This testing procedure was supervised by an experienced medical student who was blinded to the group status of the individual participant. The following trials were applied: (1) Aiming (duration, measured in seconds); (2) Steadiness (errors, measured as absolute number, and duration of errors, measured in seconds); (3) Line pursuit (errors, measured as absolute number; duration of errors and total duration, measured in seconds); (4) Tapping (tapping rate, measured as absolute number). The results of the MLS trials were transformed into age-corrected standard values. ${ }^{23}$ Because normative data from the general population have an upper age limit of 72 years, MLS results of participants beyond this age were not considered for statistical analysis. Manganese concentrations in hair and nails of the subjects were not determined.

Blood was drawn from a forearm vein of each participant. Sampling equipment and storage vials (Sarstedt Monovette, KEDTA) were controlled prior to use for contamination. The successful participation in an external quality assurance round had been certified (German Association for Occupational Medicine). $\mathrm{MN}$ in water and blood was determined by means of electrothermal atomic absorption spectrometry with Zeeman background correction using a Perkin-Elmer AAS 5100/HGA. ${ }^{24}$ To adjust for possible interactions between $\mathrm{MN}$ and iron as well as copper metabolism, ${ }^{25}$ hemoglobin, and serum coeruloplasmine, copper, and iron levels were analyzed by a certified private clinical laboratory using conventional methods. Liver function was assessed by determinations of bilirubin, alkaline phosphatase, glutamic pyruvic transaminase, glutamic oxalacetic transaminase, and gamma glutamyl transferase.

For comparison of differences in any of the clinical and laboratory measures between groups A and B Student's t-test was used, or, in the case of skewed distribution, the Mann-Whitney U-test.

\section{RESULTS}

164 subjects were eligible. 49 participants were excluded as they did not meet the above criteria, or because documentation of their well water monitoring was incomplete. 41 subjects (21 men, 20 women; mean age $57.5 \pm 10.3$ years, range $41-84$ ) were attributed to group A. In group B there were 74 subjects (41 men, 33 women; mean age $56.9 \pm 11.8$ years, range $41-86$ ). Mean ages were not different between the two groups. No dietary differences (consumption of spirits, mineral water, coffee, tea, tobacco, vegetables, and fruits) emerged between groups A and B. There were no significant differences in the mean item scores of the symptom list and of the CURS (Table). Single subjects were neurologically ill unrelated to the issue of the present investigation: Meniére's disease $(\mathrm{N}=1)$; traumatic lesion of brachial plexus $(\mathrm{N}=1)$, blepharospasm since youth $(\mathrm{N}$ $=1$ ), spasmodic torticollis since youth $(N=1)$. One subject had senile tremor, another (of group A) chemically-induced parkinsonism by exposure unrelated to rural life. Three subjects had idiopathic Parkinson's disease; all were members of group B. No subject had signs of cerebellar or anterior horn dysfunction. All neurologically impaired subjects underwent instrumental testing with the MLS. 
Table: Mean item values ( \pm SD) of the symptom questionnaire, the rating by the Columbia University Rating Scale (CURS) for parkinsonism, and for motor coordination tests (test values for the right hand are given) in the MLS between rural residents with high (group A) and low (group B) manganese content in well water. None of the differences are statistically significant.

\begin{tabular}{lrr}
\hline & Group A & Group B \\
\hline Symptom questionnaire (item number) & $3.2 \pm 3.0$ & $3.9 \pm 3.1$ \\
CURS (item number) & $1.2 \pm 1.0$ & $1.7 \pm 2.0$ \\
Aiming - Duration (sec) & $104.8 \pm 9.1$ & $102.9 \pm 10.0$ \\
Steadiness - Errors (number) & $103.9 \pm 10.3$ & $103.1 \pm 7.9$ \\
$\quad$ Duration of errors (sec) & $100.8 \pm 10.6$ & $100.2 \pm 10.5$ \\
Line pursuit - Errors (number) & $106.4 \pm 7.6$ & $106.6 \pm 8.0$ \\
$\quad$ Duration of errors (sec) & $102.3 \pm 8.1$ & $103.1 \pm 10.6$ \\
$\quad$ Total duration (sec) & $104.3 \pm 12.6$ & $100.7 \pm 15.5$ \\
Tapping - Rate (number) & $103.1 \pm 7.2$ & $103.9 \pm 10.5$ \\
\hline
\end{tabular}

Results of MLS testing were obtained for 36 participants in group A ( 18 men, 18 women; mean age $56.4 \pm 8.4$ years; range 41-72) and 67 participants in group B (35 men, 32 women; mean age $55.1 \pm 9.9$ years; range 41-72). None of the trials of the MLS was different when the results were standardized to age-corrected values (Table).

Mean $\mathrm{MN}$ concentration in blood was $8.5 \pm 2.3 \mu \mathrm{g} / \mathrm{l}$ in group A and $7.7 \pm 2.0 \mu \mathrm{g} / \mathrm{l}$ in group B (not significantly different). Mean hemoglobin, coeruloplasmine, copper, and iron values as well as liver function tests in blood and serum, respectively, were within normal ranges in both groups (data not shown). There were no correlations between actual MN blood concentrations of subjects and any clinical or instrumental parameter in either group. Separate analyses for possible confounding demographic and dietary factors within group B did not disclose differences in clinical or instrumental parameters between low and high consumers of spirits, mineral water, coffee, tea, tobacco, vegetables, or fruits.

\section{Discussion}

Ecological cross-sectional studies such as ours have methodological limitations. First, we could not control for a "sick survivor effect": subjects with disease effects possibly due to well water consumption could have migrated from the area prior to our investigation. Formal inquiries during our study and general experience in this rural region, however, argue against significant migration effects in the population under study. Secondly, we could not thoroughly exclude confounding effects of nutrition. This mostly applies for consumption of drinking water from sources other than the wells investigated. It has largely to be considered in subjects with a daily work site outside their home residence. Commercially distributed mineral waters and various foods could be neglected as confounding factors according to the unrevealing results in our risk factor analyses in group $\mathrm{B}$ between high and low consumers of any nutritional factor. Finally, we did not correlate external exposure with internal parameters of $\mathrm{MN}$ metabolism. In occupational medicine, blood $\mathrm{MN}$ concentration is thought to reflect body burden rather than actual exposure. ${ }^{17,18,26}$ The results of blood MN concentrations in our groups do not exceed reported values from normal (i.e., non-occupational) populations. ${ }^{25}$
Our results are in conflict with an earlier study from rural Greece, where neurological impairment had been attributed to elevated $\mathrm{MN}$ concentrations in pipeline-derived drinking water; ${ }^{27}$ in that study, neurological signs had been analyzed by a clinical score, without instrumental testing, and participants were ten years older on average than our probands. On the basis of our screening procedure and methodology we, therefore, think that neurological signs of aging are very likely to have contributed to the findings of the above authors.

Our data from a middle-aged population with comparable duration of exposure do not point to clinically or instrumentally detectable neurological impairment from chronic water consumption with $\mathrm{MN}$ concentrations over $0.300 \mathrm{mg} / \mathrm{l}$. In contrast with data from an occupational study, ${ }^{18}$ we did not find a higher rate of subjective complaints following chronic exposure to $\mathrm{MN}$. Nor did we observe subjects that showed signs of motor impairment suggestive of Parkinsonism. All three cases of Parkinsonism encountered during this study had been classified as typical PD and were members of group B, where MN water content was low. Ecologically, our results argue against a putative etiological role of $\mathrm{MN}$ in $\mathrm{PD}$ that may be derived from chronic exposure to drinking water concentrations above current standards. MN most likely is not a meaningful link for the epidemiologic associations between PD and living near rural wells or the use of rural well water; ${ }^{28}$ therefore, other contributing factors must be sought.

From a neurological viewpoint, chronic exposure to drinking water with high concentrations of $\mathrm{MN}$ is not a public health concern in unselected middle-aged probands. No reasons emerge from this study to lower the maximum admissible concentration level of $\mathrm{MN}$ in drinking water, which by EC recommendations is $0.050 \mathrm{mg} / \mathrm{l}^{29}$

\section{REFERENCES}

1. Yanagihara R. Heavy metals and essential minerals in motor neuron disease. In: Rowland LP, ed. Human Motor Neuron Diseases. New York: Raven Press, 1982: 233-247.

2. Editorial. Is aluminium a dementing ion? Lancet 1992; 339: $713-$ 714.

3. Barbeau A, Roy M, Bernier G, et al. Ecogenetics of Parkinson's disease: prevalence and environmental aspects in rural areas. Can J Neurol Sci 1987; 14: 36-41.

4. Rajput AH, Uitti R, Stern W, et al. Geography, drinking water chemistry, pesticides and herbicides and the etiology of Parkinson's disease. Can J Neurol Sci 1987; 14: 414-418.

5. Tanner CM. The role of environmental toxins in the etiology of Parkinson's disease. Trends Neurosci 1989; 12: 49-54.

6. Semchuk KM, Love EJ, Lee RG. Parkinson's disease and exposure to agricultural work and pesticide chemicals. Neurology 1992; 42: 1328-1335.

7. Jiménez-Jiménez FJ, Mateo D, Giménez-Roldán S. Exposure to well water and pesticides in Parkinson's disease: a case-control study in the Madrid area. Mov Disord 1992; 7: 149-152.

8. Hellenbrand W, Vieregge P, Robra B-P, et al. Die Ätiologie des Morbus Parkinson: Eine epidemiologische Perspektive mit möglichen Implikationen für die Prävention. Nervenarzt 1993; 64: 770-786

9. Barbeau A. Manganese and extrapyramidal disorders. Neurotoxicology 1984; 5: 13-36.

10. Aschner M, Aschner JL. Manganese neurotoxicity: cellular effects and blood-brain barrier transport. Neurosci Biobehav Rev 1991; 15: 333-340.

11. Brouillet EP, Shinobu L, McGarvey U, et al. Manganese injection into the rat striatum produces excitotoxic lesions by impairing energy metabolism. Exp Neurol 1993; 120: 89-94. 
12. Huang C-C, Chu N-S, Lu C-S, et al. Chronic manganese intoxication. Arch Neurol 1989; 46: $1104-1106$.

13. Calne DB, Chu N-S, Huang C-C, et al. Manganism and idiopathic parkinsonism: similarities and differences. Neurology 1994; 44: 1583-1586.

14. Yamada M, Ohno S, Okayasu R, et al. Chronic manganese poisoning: a neuropathological study with determination of manganese distribution in the brain. Acta Neuropathol (Berl) 1986; 70: 273 278.

15. Uitti RJ, Rajput AH, Rozdilsky B, et al. Regional metal concentrations in Parkinson's disease, other chronic neurological diseases, and control brains. Can J Neurol Sci 1989; 16: 310-314.

16. Dexter DT, Carayon A, Javoy-Agid F, et al. Alterations in the levels of iron, ferritin and other trace metals in Parkinson's disease and other neurodegenerative diseases affecting the basal ganglia Brain 1991; 114: 1953-1975.

17. Saric M, Markicevic A, Hrustic O. Occupational exposure to manganese. Br J Ind Med 1977; 34: 114-118.

18. Roels H, Lauwerys R, Buchet J-P, et al. Epidemiological survey among workers exposed to manganese: effects on lung, central nervous system, and some biological indices. Am J Ind Med 1987: 11:307-327.

19. Graham DG. Catecholamine toxicity: a proposal for the molecular pathogenesis of manganese neurotoxicity and Parkinsons's disease. Neurotoxicology 1984; 5: 83-96.

20. Hogstedt C, Andersson K, Hane M. A questionnaire approach to the monitoring of early disturbances in central nervous functions. In: Aitio A, Riihimaki V, Vaninio H, eds. Biological monitoring and surveillance of workers exposed to chemicals. Washington: Hemisphere Publ Corp, 1984; 275-287.
21. Yahr MD, Duvoisin RC, Schear MJ, et al. Treatment of parkinsonism with levodopa. Arch Neurol 1969; 21: 343-354.

22. Schoppe KJ. Das MLS-Gerät: Ein neuer Testapparat zur Messung feinmotorischer Leistungen. Diagnostica 1974; 20: 43-46.

23. Sturm W, Büssing A. Ergänzende Normierungsdaten und RetestReliabilitätskoeffizienten zur Motorischen Leistungsserie (MLS) nach Schoppe. Diagnostica 1985; 31: 234-245.

24. Hallas DJ, Fells GS. Determination of manganese in serum and urine by electrothermal atomic absorption spectrometry. Ana! Chim Acta 1981; 129: 205-211.

25. Saric M. Manganese. In: Friberg L, Nordberg GF, Vouk VB, eds. Handbook on the Toxicology of Metals. Vol II: Specific metals. Amsterdam - New York - Oxford: Elsevier, 1986; 2nd Edition: 354-386.

26. Järvisalo $J$, Olkinuora $M$, Kiilunen $M$, et al. Urinary and blood manganese in occupationally nonexposed populations and in manual metal arc welders of mild steel. Int Arch Occup Environ Health 1992; 63: 495-501.

27. Kondakis XG, Makris N, Leotsinides M, et al. Possible health effects of high manganese concentration in drinking water. Arch Environ Health 1989; 44: 175-178.

28. Goldsmith JR, Herishanu YO, Abarbanel JM, Weinbaum Z. Clustering of Parkinson's disease points to environmental etiology. Arch Environ Health 1990; 45: 88-94.

29. EEC: Richtlinie des Rates vom 15.07.1980 über die Qualität von Wasser für den menschlichen Gebrauch (80/778/EWG). Amtsblatt der Europäischen Gemeinschaften vom 30.08.1980 Nr.L229/11-29, 